УДК 657.01

DOI 10.31882/2311-4711.2019.25.20

\author{
Хальзова Анна Михайловна \\ кафедра бухгалтерского учета и налогообложение \\ Российский экономический университет имени Г.В.Плеханова, \\ Российская Федерация, г. Москва, 117997, Стремянный пер., 36 \\ E-mail:anya-khalzova@mail.ru
}

\title{
ЭКОНОМИЧЕСКАЯ СУЩНОСТЬ АМОРТИЗАЦИИ ОСНОВНЫХ СРЕДСТВ
}

\begin{abstract}
Аннотация. В статье проведено исследование экономической сущности амортизации основных средств и необходимости создания амортизационного фонда. Особое внимание уделено терминологическому и экономическому пониманию «амортизация», «износ». Рассмотрено понимание термина «амортизация» российскими и зарубежными исследователями. По результатам проведенного исследования представлено авторское мнение о понятии амортизации основных средств и влиянии применения методов амортизации методов на стоимостную оценку амортизируемых активов. Статья выполнена под научным руководством к.э.н., доцента Морозовой Т.В., кафедра бухгалтерского учета и налогообложения, РЭУ им. Г.В. Плеханова.

Ключевые слова: амортизация основных средств, амортизационные фонды, основные средства
\end{abstract}

Введение. В процессе использования основные средства подвергаются износу: моральному и (или) или физическому. В связи с этим возникает необходимость их замены более современными и усовершенствованными моделями. Выручка от реализованных товаров и услуг является основным источником денежных средств, направленных на замену старых объектов новыми $[1,2]$.

При этом в цену товаров и услуг включается частичное погашение стоимости действующих основных средств. Данный процесс называется амортизацией. Вместе с тем, обладая полной информацией о каждом элементе основных средств в производственном процессе, о факторах, которые влияют на использование основных средств, можно выявить методы, при помощи которых совершенствуется порядок начисления амортизации основных средств предприятия, как один из важных составляющих финансовой модели организации. Можно отметить неоднозначность понимания этого термина в научной литературе, а также предложения специалистов о необходимости воссоздания амортизационных фондов [3, 4].

Основная часть. В процессе ведения хозяйственной деятельности организации, для целей производства продукции, выполнения работ, оказания услуг, а также для управленческих нужд необходимы основные средства. Доля в активах объектов основных средств зависит от вида деятельности организации. Для производственных предприятий такая доля существенна, для организаций, оказывающих работы, услуги, может быть незначительна.
Такие основные средства, как недвижимость, автотранспортные средства могут выступать гарантом надежности организации [5]. С точки зрения инвесторов, кредиторов ликвидная недвижимость, другие объекты, имеющие спрос на свободном активном рынке, являются залогом платежеспособности организации и серьезности намерений в развитии бизнеса [6]. В процессе своей эксплуатации объекты морально и физически изнашиваются и в практической деятельности необходимы приемы, которые могут учесть экономическую и качественную составляющую переноса их стоимости [7].

Известный ученый, Соколов Я.В. отмечал, что первое упоминание амортизации встречается во флорентийских фирмах XV века. Тем не менее, амортизацию стали воспринимать как элемент бухгалтерского учета лишь к середине XIX века. В тот период начались массовые железнодорожные строительные работы. Данный процесс требовал существенных коллективных капиталов, а расходы, связанные со строительством, отражались в момент их возникновения [8]. Таким образом, суммы фиксировались в самом начале строительства. В результате возникала достаточно высокая прибыль, так как не происходило начисление амортизации, и, как следствие, акционеры требовали выплаты дивидендов. «Но подлинные хозяева не хотели расставаться с выручкой, поэтому создавали фонды обновления (реновации). Предполагалось, что, когда средства компании будут изношены, у управления железной дороги будут средства, чтобы восстановить ликвидируемые средства» [9]. 
После этого амортизацию начали понимать, как фонд. Обычно его разделяли на две части: первая была необходима для покупки или создания новых объектов вместо старых (реновация), а под второй понимали накопление средств для капитального ремонта. Как отмечал в 1901 г. С.А. Беннинг в своей работе «Счетоводство и амортизация», слово «амортизация» взято от французского глагола amortir (убивать, погашать, приводить к постепенному вымиранию) [10].

Неоценимый вклад в данную теорию внес глава петербургской школы бухгалтерского учета Е.Е. Сиверс. По его мнению, амортизация - это фонд обновления, создаваемый за счет части выручки. Он предполагал, что, когда имущество будет изношено, у предприятия будут деньги для восстановления этого объекта [11].

При этом Е.Е. Сиверс считал, что должен создаваться новый фонд, который учитывает один из источников собственных средств предприятия, а также что статья пассива баланса «Амортизационный фонд» — это резерв, который обеспечен не основными, а оборотными средствами [12].

Такая позиция активно использовалась и на практике. Например, в конце $1980-х$ гг. типовая форма бухгалтерского баланса промышленного предприятия содержала в пассиве баланса статью: «Износ основных средств». Однако, данная форма баланса в России просуществовала только до 1992 г. Помимо советских ученых над экономическим понятием «амортизация» вели работу и зарубежные экономисты.

Так, проанализировав причины экономического краха, времен Великой депрессии в США (19291933 годы), Дж.М.Б. Хокси, подверг резкой критике отсутствие единого подхода в области начисления амортизации, так как в то время на практике не существовало никаких строгих правил, а компании даже могли не указывать, какие методы они применяют [13].

Раннее было отмечено, что у компаний есть возможность создавать амортизационные фонды, которые будут состоять из амортизационных отчислений, и использоваться для замены основных средств после того как они подвергнутся износу. В этом случае подразумевается искусственное перераспределение пассивных статей в балансе, так как логично предположить, что создание фонда не обеспечит организацию дополнительными денежными средствами.

Также можно отметить, что приобретение активов как краткосрочных, так и долгосрочных, возможно лишь за счет денежных средств. Данный фонд можно представить в двух формах: денежной и неденежной. Денежный формат представляет возможность накопления (резервирования) высоколиквидных активов в качестве обеспечения возмещения изношенных объектов основных средств. В частности, в бухгалтерском учете такой процесс может быть проведен через создание субсчетов на счетах учета денежных средств.

По нашему мнению, такой подход не учитывает уровень потери покупательной способности денежных средств, которые зарезервированы для накопления по целевому назначению. Такой же отрицательный аспект можно отметить при резервировании других ликвидных активов. Например, размещение денежных средств на депозитных счетах должно быть экономически оправданным, а ожидаемые доходы должны быть выше ожидаемой потери покупательной способности денежных средств [14]. При этом функцию контроля изношенности объектов основных средств может выполнять счет отражения накопленной амортизации, что не влечет за собой необходимость создания амортизационных резервов в составе собственного капитала [15]. Кроме того, исходя из разницы в стоимостной оценке основных средств, отраженных в балансовом отчете и справедливой стоимостью объектов основных средств, может быть не учтен фактор их востребованности на рынке. Такая разница может возникать в случае отражения в учете объектов основных средств по первоначальной, а не по восстановительной стоимости. Исходя из этого, считаем, что создание амортизационного фонда для покрытия изношенности объектов основных средств не является актуальным.

Заключение. На основании вышеизложенного, можно сделать вывод, что, не смотря на сложную историю формирования термина «амортизация» и существование множества его трактовок, в настоящее время научный мир фактически сошелся на том, что в процессе эксплуатации основные средства постепенно изнашиваются, и для формирования ресурсов на их воспроизводство стоимость изношенной части основных средств включается в затраты на производство продукции, работ, услуг путем начисления амортизации. Саму процедуру амортизации можно считать инструментом по отражению процессов учета физического и морального устаревания объектов основных средств. Вопросы создания амортизационного фонда для коммерческих организаций можно считать спорными и создание амортизационного фонда для покрытия изношенности объектов основных средств не является актуальным. 


\title{
Список использованных источников
}

1. Беннинг С.А. Счетоводство и амортизация. Спб.: Издание М.В. Кечеджи-Шаповалова, 1901.30 с.

2. Галайда А.М. Проблемы бухгалтерского и налогового учета амортизации лизинговых активов // Лизинг, 2017, No 2. C. 28-33.

3. Соколов Я. В. Бухгалтерский учет и его закон // Бухгалтерский учет. 2005. № 10.

4. Турищева Т.Б. Эволюция контроля и его роль в современной условиях // Современная наука: актуальные проблемы теории и практики. Серия: Экономика и право. 2017. № 9. С. 38-41.

5. Дюжов А.В. Теоретические аспекты применения бюджетно-налогового федерализма в РФ //Экономика, статистика и информатика. Вестник УМО. 2013. № 4. С. 51-54.

6. Чиркова М.Б., Малицкая В.Б., Леонова О.И. Сравнение российского учета резервов под обесценение финансовых вложений с международно признанными стандартами/ М.Б. Чиркова, В.Б. Малицкая, О.И. Леонова // Аудит и финансовый анализ. 2015. №2. С. 69-76.

7. Сокольникова И.В. Оценка инвестиционных проектов в условиях значительной волатильности факторов внешней среды // Транспортное дело России. 2016. № 2. С. 91-94

8. Братцев, В.И. Государственное регулирование сельскохозяйственного производства с использованием системы налогообложения/В.И. Братцев. -М.: ГНУ ВНИИЭСХ, 2012. -286 с.

9. Кутер М.И., Кузнецов А.В., Мамедов Р.И. Современный взгляд на концепции амортизации // Экономический анализ: теория и практика. 2008. № 24. С. 12-17.

10. Морозова Т.В. Оценка стоимости предприятий // Бухгалтерский учет. 1995. № 8. С. 28-31.

11. Комарова И.П., Новикова Е.С., Устюжанина Е.В. Экономика взаимности: хорошо забытое новое // Вестник Российского экономического университета им. Г.В. Плеханова. 2017. № 5 (95). С. 3-11.

12. Косов М.Е. Формы реализации бюджетных инвестиций, повышение их эффективности // Экономический анализ: теория и практика. 2019. Т. 18. № 1 (484). С. 83-95.

13. Турищева Т.Б. основы формирования, роль и место внутреннего контроля в системе управления автономных учреждений // Экономика и предпринимательство. 2017. № 8-1 (85). С. 1171-1174.

14. Понкратов В.В. Базовые критерии дифференциации ставки НДПИ по природному газу // Финансы. - 2006. №2. - С. 36-38.

15. Куликова Л. И. Бухгалтерская концепция амортизации: история становления и развития // Международный бухгалтерский учет. 2015. №37. С. 2 - 15.

\author{
Khalzova Anna Mikhailovna \\ Department of Accounting and Taxation \\ Plekhanov Russian University of Economics \\ Russian Federation, 117997, Moscow, Stremyanny lane, 36 \\ E-mail:anya-khalzova@mail.ru
}

\section{SUBSTANCE OF DEPRECIATION OF FIXED ASSETS}

Summary. The article conducted a study of substance of depreciation of fixed assets and necessity of creation of depreciation funds. Special attention is paid to the terminological and economic understanding of "depreciation". It was considered the presentation of the term "depreciation" by the Russian and foreign professors and economists, as well as the order of reflection of depreciation in Russia in the late 1980s. According to the results of the study, the author's opinion was presented on the concept of depreciation of fixed assets and the impact of depreciation methods on the valuation of depreciable assets.

Keywords: depreciation of fixed assets, depreciation funds. 